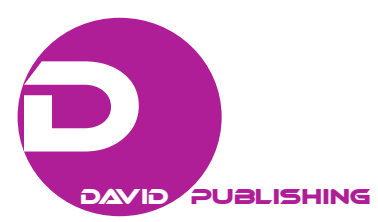

\title{
Islamic Finance in Theory and Practice
}

\author{
Muhamad Abdul Aziz Muhamad Saleh Jumaa \\ City University College of Ajman (CUCA), Ajman, UAE
}

\begin{abstract}
Perspectives of the early scholars of Islamic management of an account concurred that the arrangement of organization partnership in general and Murabah (benefit sharing) specifically is the fundamental technique on which Islamic banks must depend on contributing their money to related assets. Also, the research has found that financing under the Islamic management of an account has decreased intensely from the methodology created by the early scholars. In reality, these banks have received obligation based on financing techniques and underestimated the routines for financing taking into account benefit and loss sharing. This adjustment in financing technique has perversely influenced the bad name and the desire tied with the monetary part of these banks. The study focused on the reason behind the gap between theory and practice in Islamic finance. So, the study was divided in two parts: the first theoretical part of Islamic economy and Islamic banking system, the second practical part by analysing and evaluating the relative distribution of Islamic financing methods in four famous Islamic banks. The study selected a group of Asian Islamic banks as a model for analysis and evaluation through the period from 2012 to 2014. The study concluded that the gaps result from the misuse of the roles and norms of Maqasid Al-Shariah along with the diversion in the relatively allocation of the financing methods toward debt instruments rather than equity instruments.
\end{abstract}

Keywords: Islamic banks, Islamic finance, conventional banks, accounting, finance, financial statements

\section{Introduction}

Two perspectives shape the relationship in the middle of Islam and account. One is Islamic law, the Shariah cases to control all parts of life, moral, and social, and to envelop criminal as ill as common preview. Each demonstration of devotees must adjust to Islamic law and watch moral guidelines got from Islamic standards. These moral standards characterize what is genuine, reasonable, and simply, the nature of corporate obligations and the needs to society. Second, notwithstanding giving an arrangement of business morals, certain Islamic financial and money related standards have an immediate effect on monetary frameworks. These standards incorporate, in particular, the organization of zakat (the religious charity) and the forbiddance of Reba (usury) and the foundation of an interest free financial framework.

The two speculatives in Islamic jurisprudence are the rightful appropriate decades who can rely on them in the establishment of the Islamic banks served as usurious banks.

Initiating looking for other tools which are more profitable and less risky as well as easier application resorted to finance instruments of business for margin profit, which led to the emergence of a variety of funding methods such as Murabaha and Ijara. These operations overshadowed the other and it is what made the

Muhamad Abdul Aziz Muhamad Saleh Jumaa, Ph.D., assistant professor, Chair of Department of Finance \& Accounting, City University College of Ajman (CUCA), Ajman, UAE.

Correspondence concerning this article should be addressed to Muhamad Abdul Aziz Muhamad Saleh Jumaa, Department of Finance \& Accounting, City University College of Ajman (CUCA), 18484, Ajman, UAE. 
practical application of the experience of Islamic banks deviate from the theory which Italians have developed, which still has the support of most of those people who are interested in the Islamic financing system of the modern era.

Is this fact makes people wonder about the extent of deviation witnessed practical experience of Islamic banks which have a framework for a theory? The question is also about how these banks need to evaluate their career?

And it is what the research will try to answer in the study which aims to shed light on the financing function of sites in the Islamic banking currently by monitoring the experiences of some Islamic banks relying on high-descriptive analytical method which includes the search along with the point view from issuing the book of Islamic banking.

Practical side the stufy will focus on analysing policy of funding in the financial annual reports for some Islamic banks relying on financial statements for being more styles appropriate to the nature of the study and its objective is to evaluate the extent of the gap between the theoretical and practical side of Islamic finance.

\section{Literature Review}

Utilizing from different studies that follow the year 2000, which presented the subject of Islamic banks notion and highlighted its congruity for Islamic account; clarified the real components of Islamic law and preclusion concerning Islamic account; addressed the utilization of "nominate" that contracts and guarantees (or legitimately tying one-sided endeavours) in organizing Islamic monetary issues; and discussed the administrative that issues an defined administration and social obligation.

Also a lot of studies and researches discussed the success factors of Islamic banks and the problems faced by Islamic banks.

- Monzer Kahf (2005) studied entitled: "The success factors of Islamic banks".

Kahf, in his study, discussed several cases related to the standards of success of the Islamic banking, he selected a sample from famous Islamic banks "Bahrain Islamic banks" in four years from 2001-2004, and concluded a success criterion through basic indicators relating to Islamic banks profit system.

- Nasser Al Ghareeb studied in 2010, entitled: "Islamic banking assets and operating issues". 2

The study discussed the legitimacy for banking issues and the history of Islamic banking and Islamic funding framework. Also he handled the problems that are faced by Islamic banks and their relationship with the central bank; he discussed the measurement and distribution of profits in Islamic banks and determined the criteria of distributing profits.

- Manawar Iqbal studied, in 2007, entitled: “A comparing study between Islamic and conventional banks in the nineties". 3

The study's purpose was to discuss the Islamic banks system in order to bridge the gap in data from 2003-2006. The researcher used multiple hypotheses, experiments, and analytical equations to achieve the goals needed to compare Islamic banks with conventional banks.

\footnotetext{
${ }^{1}$ Kahf Monzer (2005). The success factors of Islamic banks, Islamic Study and Training Institute, Islamic Development Bank, Jeddah, KSA.

${ }^{2}$ Nasser Al Ghareeb (2010). Islamic banking assets and operating issues, Islamic Study and Training Institute, Islamic Development Bank, Jeddah, KSA.

3 Manawar Iqbal (2007). A comparing study between Islamic and conventional banks in the nineties, Islamic Study and Training Institute, Islamic Development Bank, Jeddah, KSA.
} 


\section{Study Objective}

The main purpose of this study is to:

(1) understand the basic rules and sources of Islamic financing;

(2) address the reason behind the gap between theory and practice in Islamic financing that violate the Islamic economic principles.

\section{Study Question}

(1) Do banks misuse the rules and norms of Maqasid Al Shariah, and if yes in what ways?

(2) Who is responsible for the misuse of the rules and norms of Maqasid Al Shariah?

(3) Why Islamic banks depend mostly on debt instruments rather than equity instruments?

\section{Hypotheses}

H1: The gap results from the misuse of the roles and norms of Maqasid Al Shariah only.

H2: The gap results from the misuse of the roles and norms of Maqasid Al Shariah along with the diversion in the relatively allocation of the financing methods between debt and equity.

\section{Methodology}

The study will depend on two sources, first on principle of Islamic economy which relays on The Holy Quran, The Sunnah, and Maqasid Al Shariah that have not been changed since the Islamic revolution and compare them with the new methodology used by Islamic banks in offering the new services in the absence of clear direction from both "Quran and hadith".

Secondly, analysing and evaluating different financing methods offered by Islamic banks in Asia.

\section{A Theoretical Method of Islamic Banking Financing}

\section{Basic Principles of Sharia Law}

- The Holy Quran includes message and command from Allah which has been sent down by Prophet Muhammad peace is upon him to guide people to the right direction.

- Hadith "Sunnah" is a collection of information, history, account, variation, and records of the Sunnah that was created by Prophet Muhammad (P.B.U.H.). Hadith also describes the prophet's behaviour, method of any action, declaration, and saying under assortment of circumstances during prophet's lifetime.

- Ijma is the unanimity of opinion on agreements of Muslim juries on any problem to determine a special legislation.

- Qiyas and Ijma are branches of Sharia law, these sources are a solely complete and overall the Sharia law itself has yet to be formulated so as to adjust foreseen consequences and also to overlook Islamic banking system with it.

- Means of legislation: ijm'a, qiyas, and ijtihad.

- Typically, most analysts of Shari'a write that ijm'a is the third source of legislation. In reality, it is ijtihad. One may consider ijtihad to be the third source because this is the result of either individual scholarly effort or collective scholarly and juristic analysis. The latter, or collective, ijtihad is ijm'a. The areas which comprise ijtihad include: qiyas, istihsan, and urf (Archer \& Abdel Karim, 2007; Choudhry \& Mirakhor, 1997).

- Gharar (Interest): Gharar (Interest) is not allowed in Islamic banks, but in commercial banks, they may use 
Gharar to the client and get as much profit as they can from the customer.

Gharar transaction occurs when one party can only benefit by the other's loss. Under conditions of uncertainty, commercial insurance is given as an example, since either the insured pays a premium and receives no counter value, or the insurer pays out much more on a claim than was received by way of premium. Professor Mahmoud el-Gamal stated that Gharar involves the trading of unknown risk. For example, if a home owner insures his home conventionally against damage by fire, then the homeowner can be said to have separated the risk of fire from the right of ownership of the house (in other words, to have "unbundled" risk and ownership). The insurance company is paid to accept the risk of damage by fire, while the homeowner retains ownership of the house.

\section{Establishment of Islamic: Brief Historical Perspective}

Figure 1 illustrates a brief history about the establishment of Islamic banks and institutions (Archer \& Abdel Karim, 2007, p. 27).

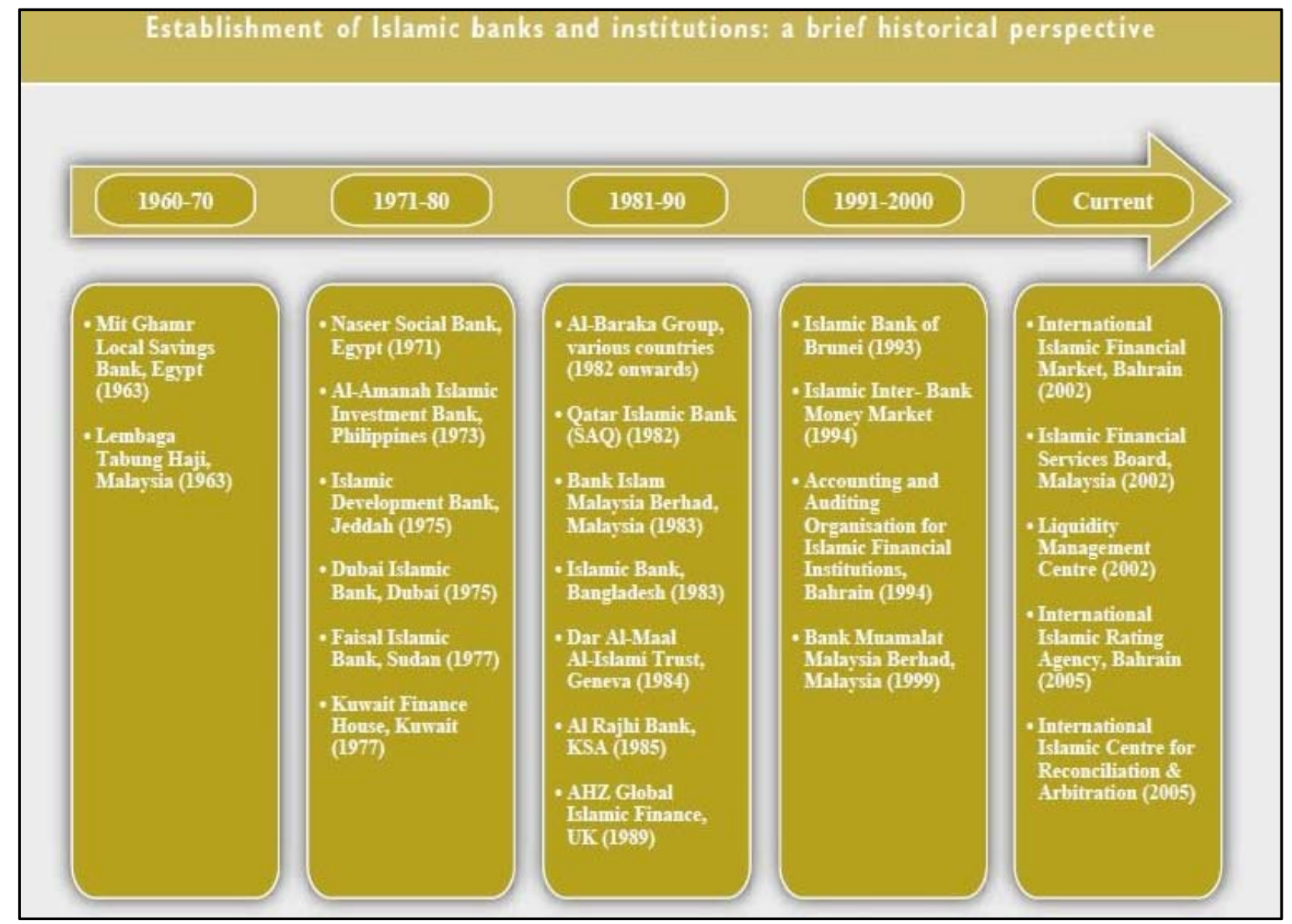

Figure 1. Establishment of Islamic banks and institutions: a brief historical perspective.

\section{Basis, Objectives, and Principles of Islamic Economics as a System}

An Economic System is an organised way in which a state or nation allocates its resources and apportions goods and services in the national community.

The ethical base of the Islamic Economic System provides the Value System through which it governs all forms of economic interaction in society (e.g.: religion, ideology, ideals, morals, etc.). 
Thus, the Islamic Economic System has its basis and objectives on one hand and with its axioms and principles on the other hand.

Islamic economics created a new system, the features of which can be defined as:

(1) It describes, analyses, and prescribes with a background of Shariah.

(2) It deals with production, consumption, and distribution activities of human beings according to Islamic worldview.

(3) It offers economic and financial choices according to Islamic norms.

(4) It is part of a Religion (Islam).

(5) It depends on different sources for the theory of knowledge (Epistemological sources) i.e.: the Holy Qur'an and the Sunnah.

Its fundamental concepts - being based on the Qur'an — are divine and not open for changes in meaning.

\section{Methodology of Islamic Economics}

The methodological postulates of Islamic economics can be summarised as follows (Kahf Monzer, 2003):

- Socio-tropic individual, for whom independence as ill as social concern is an essential.

- Behavioural postulates: socially concerned God-cognizant people who

- in looking for their preference are worried with the social great;

- conduct financial movement rationally as per Islamic limitations with respect to individual and social environment and the great beyond;

- in attempting to expand his/her utility try to amplify social welfare too by considering the hereafter.

- The primary component of financial operation in the Islamic framework is market exchange separated through an Islamic process that does not harm the society environment.

\section{Mechanisms and Instruments of Islamic Economic System}

The objective of the establishment of the Islamic financial system is to accept the case that Islamic financial system is an "option framework with its particular quality, aphorisms, foundational standards, and organizations".

Islamic financial system gives establishments honing the Islamic economy differently contrasted with other conventional system. These Islamic establishments are "identified with business (muamalat) additionally to the administration of the economy and business sector, for example, (hisbah) as a regulative foundation for the business sector framework".

Islamic economic and financial activities are shaped by three kinds of measures and institutions:

(1) Positive measures, such as Al Zakah to react to the necessities of poor people and ease destitution. Strategies have been produced to methodically deal with the Al Zakah stores: rather than essentially offering assets to the poor for their quick utilization, "creating ventures for the supportability, survival, and congruity of the financially less blessed is the new technique with Al Zakah reserves". "Hisbah is another vital positive organization in the Islamic monetary framework that manages the business sector component by reacting to its disappointments and deficiencies and beating its overabundances".

(2) Voluntary measures, for example, Al Sadaqah goes for giving the quick needs of a person.

Al Waqf (pious foundation) is a piece of the voluntary sector, pointing to give merchandise and benefits, wellbeing administrations, instruction, sustenance appropriation, and so on. Notwithstanding, human advancement undertakings are done so as to improve their commitments to the financial advancement of the social orders.

(3) Prohibitive measures, such as Reba money related action. (Islamic financial framework proposes 
benefit and misfortune sharing and chance taking and sharing against foreordained capital increases to thought process people to effectively take part in the economy).

Takaful or Islamic protection is another critical part of Islamic money related establishments, which work on a non-premium premise. It gives Islamic consistent protection items to people and business, yet it likewise oversees reserves in an Islamic way, adding to financial development.

The presence and effective operation of these establishments are an indication that Islamic financial matters are its very own arrangement with its qualities, sayings, and foundational standards, furthermore, with its specific organizations, which work inside of the Islamic structure (Hassan \& Lewis, 2007).

\section{Islamic Finance: Ideals \& Realities}

However, Islamic finance follows a very pragmatic development that is located within the neo-classical paradigm.

Along these lines, in its present state, Islamic account does not appear to share the foundational cases of Islamic financial aspects. A particular component of the late talks on Islamic managing an account has been the developing wedge between its routine hypothesis and current practice.

The outcome, subsequently, has been the uniqueness between the suspicions, standardizing standards, and goals of Islamic financial matters as a framework and Islamic money as an instrument of that framework.

In other words, a particular element of the late talks on Islamic managing an account has been the developing wedge between its customary theory and current practice. The substances of budgetary markets which organize monetary motivating forces as opposed to religious behavioural standards has "constrained" Islamic money to wind up a portion of the worldwide monetary framework, in which it is perceived as heterogeneity of monetary items denied of their worth framework.

Currently, Islamic fund speaks to half breed monetary results of the worldwide money related framework. In this manner, the distinction has been decreased to detail, and the worth framework is no more said past quoting so as to portray the disallowance of Reba verses in the Qur'an.

Despite what might be expected, Islamic financial aspects' perusing of the same Shariah rules underscore social equity, need satisfaction and redistribution, in particular a socio-political perusing inside of a political economy structure.

Tolerating the present condition of Islamic money is a trade-off earnestly requiring new model of improvement inside of the idea of Islamic good financial framework.

The failure of Islamic finance needs to be urgently moderated.

\section{Basic Principles of Islamic Financing}

Fundamental principles of the Islamic finance. Islamic Finance gives high thought to the concept of social justice and deals with poor people and frail.

Development of Islamic finance. In the course of the most recent 40 years, Islamic saving money has risen as a reasonable and productive model of budgetary intermediation. Trusts were this new model of monetary intermediation which could convey to society development and improvement, as Islamic managing an account satisfies the religious prerequisites of an extensive rate of worldwide populace and extends the decision for all, in this way expanding productivity and asset distribution.

Evolution of Islamic financial institutions. The Islamic Finance Sector is showing fast development modes with a yearly development rate of more than $15 \%$, but it does not cover the Islamic nations; additionally, 
include around 360 financial establishments in more than 50 nations.

According to "islamicfinance.com", the size of the Islamic finance market is evaluated to be in the reach from $\$ 1.66$ trillion to $\$ 2.1$ trillion with desires of business sector size to be $\$ 3.4$ trillion by end of 2018 .

In light of $\$ 1.66$ trillion, Islamic Finance resources spoke to $1 \%$ of the worldwide money related business sector of $\$ 127$ trillion in assets (Figures 2, 3, 4, and 5) (Hussein, 2012).

Asset value per asset.

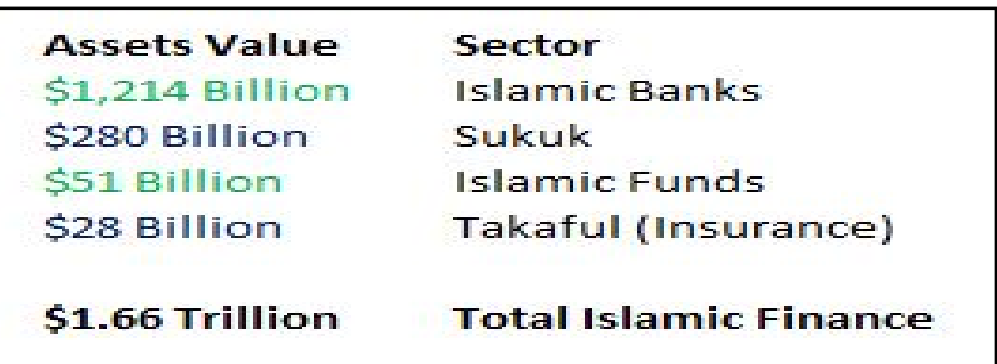

Figure 2. Islamic finance assets by domicile.

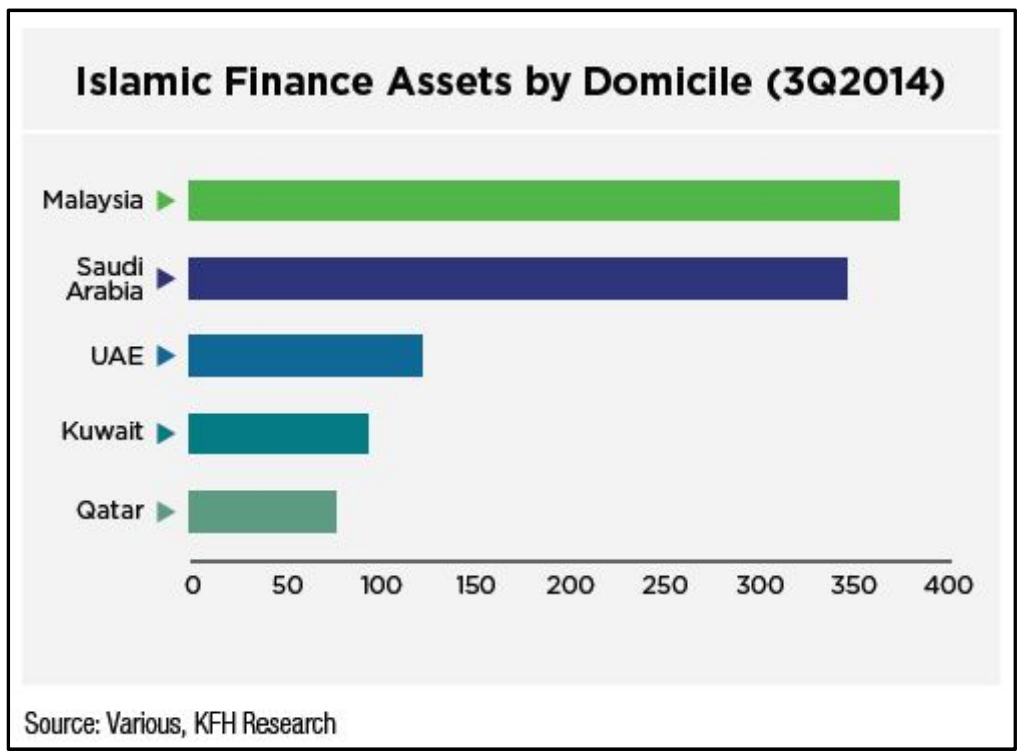

Figure 3. Global Islamic finance assets.

\section{Global Islamic Finance Assets (2009-2014E)}

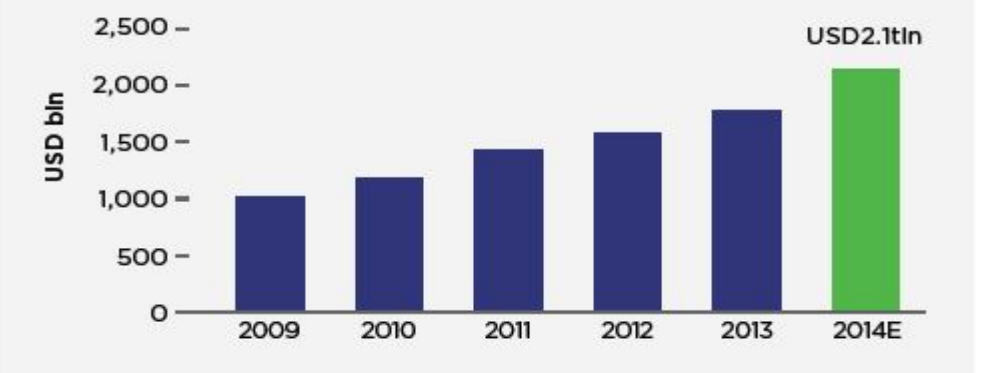

Figure 4. Global Islamic finance assets (2009-2014E). 


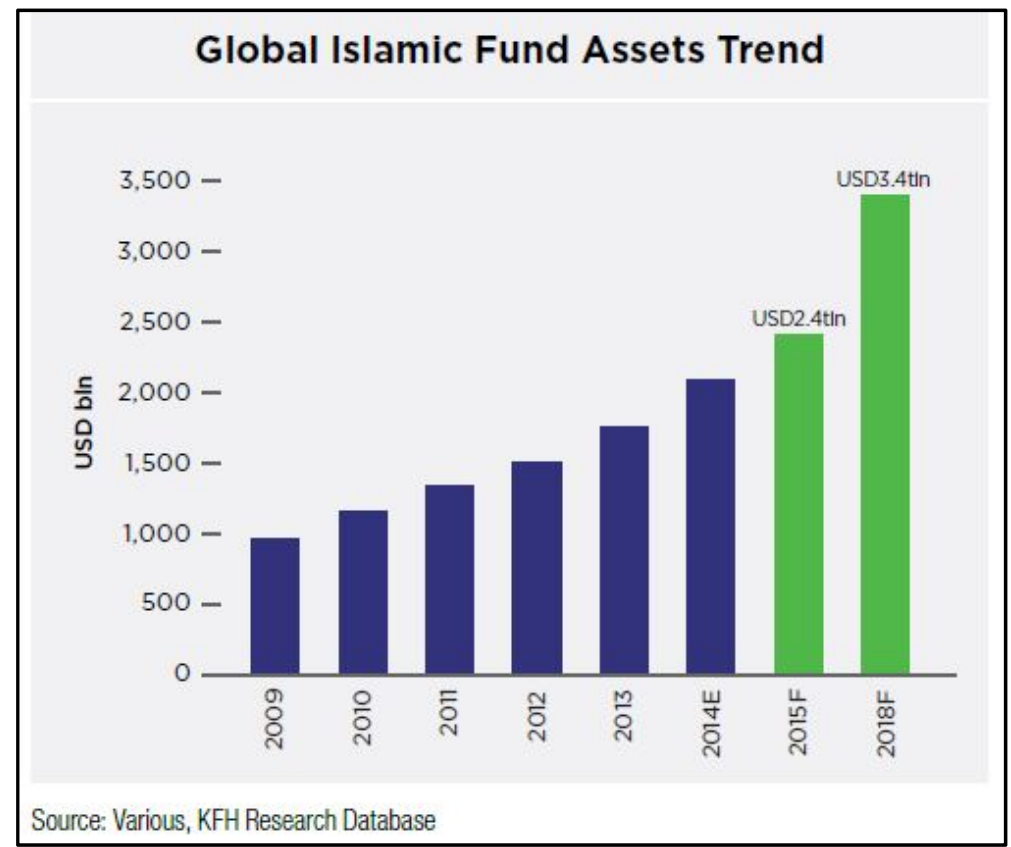

Figure 5. Global Islamic fund assets trend.

Many commercial global banks are providing Islamic banking services through special "Islamic Windows".

\section{Islamic Finance Methods}

\section{Financing Instruments}

Murabaha in Islamic banking. Murabaha is the major channel of financing in Islamic banking because it's a legal commercial transaction in Islamic law; furthermore, it provides customers with finance without Reba since the Islamic bank buys the commodity and sells it to the customer by instalments which meet his cash flows ability.

The bank receives an agreed profit in return. Bank's profit $=$ selling price - buying price. The bank gets this profit from the followings (Shaker, 2010):

(1) It provides the customer with the appropriate financing versus acceptable profit.

(2) It bears a risk during the period between buying and selling the commodity to the customer.

The study can use Murabaha to finance all legal and commercial transaction.

Bank can carry out Murabaha for deferred purchasing orders which are listed below:

- First phase: The customer applies for product purchasing order through Murabaha.

- Second phase: Secondly, the bank studies the customer's credit worthiness through analysing his character, capital, capacity, conditions, collaterals, commodity legality, and commodity of profitability which must be able to comply with the bank's credit policy.

- Third phase: Third step is that, if the bank agreed with customer's statements then the customer would have to sign a contract of promising purchasing order and pay the demanded amount to the bank.

- Fourth phase: The bank contacts the supplier and buys the product for its customer, and they would bear a risk during the period in which he owns the commodity. Usually, the bank retains an agent on the costumer's behalf to buy the product and own it under his name until it is completely under the name of the costumer.

- Fifth phase: In fifth phase, the bank signs a selling contract with the customer after the collaterals for the credit have been accepted and approved by the bank. 
- Sixth phase: The customer will be committed to pay the instalments on time, but if he defaults to pay on time (ta'asa), the bank would study his situation:

- If he was insolvent (mo'ser), he will be given an extension period without any addition fees. Verse: (wa in can tho o'srah fnathertn ela maisera);

- If customer owns the money but he does not pay, the bank will charge him the expenses that the bank bears (the real expenses not the expected ones).

- Seventh phase: Finally, if the customer fails to fulfil the promise and does not receive goods, the bank will sell the product. If there are losses, he will take it from the safe margin.

- However, in the reality, the customer is not contacting with the banks directly, but the customer is going to the showroom and chooses the car that they want to sale and agree with the exhibition, and they will agree how much he has to pay, after that the bank will send delegate to sign the agreement with him, then the process will be completed by the banks and the owners of the car, in this situation, it will be considered as (Gharar) interest, the bank is involved in cheating the customer in this way.

- Furthermore, the bank should negotiate with the owner of the car not the customer and the customer should not contact with the owner of the car without the presence of the third party (bank).

\section{Case Study}

Calculating the product cost. The cost $=$ purchasing expense + all expense until the commodity would be received. Suppose that one customer asks the bank to import goods for him through Murabaha, The costs and expense Ire: $($ Invoice $)=1,000,000$ AED; Credit expenses $=100,000$ AED; Customs tariffs $=200,000$ AED; Transportation charges $=50,000$ AED; So, the total cost $=1,300,000$ AED.

Calculate Islamic bank's profit. Suppose that bank agrees with customer that: Bank profit $=15 \%$ of the total cost; Safe margin $=300,000$ AED; Murabaha duration: 20 months; Total cost $=1,300,000$; Minus profit margin $-300,000$ AED; Finance amount $=1,000,000$; Plus Murabaha profit $+150,000$; Total indebtedness $=$ 1,150,000 AED; Instalment amount $=57,500$ AED.

Profit $\&$ instalments distribution. The instalments plus profit are: Year 2000: 8 instalments $57,500 \times 8=$ 460,000 AED; Year 2001: 12 instalments 57,500 × $12=690,000$ AED. The profit distribution: Instalment's share of the profit $=150,000 / 20=7,500$ AED; First year profit $=7,500 \times 8=60,000$ AED; Second year profit $=7,500 \times 12=90,000$ AED.

The customer breaches the contract and does not receive the product. Assuming that the customer refuses to buy the product after the bank buys it: (Turnover) Total cost $=1,300,000$ AED; Safe margin = 300,000 AED. The bank sold the goods: The bank sold the goods at price $=1,400,000 \mathrm{AED}$, in this situation, bank returns the safe margin $(300,000)$ plus 100,000 profit. The bank sold the goods at price $=1,100,000$ AED, in this situation, banks returns 100,000 AED of safe margin 10,000 = (Safe margin - losses amount). The bank sold the goods at price 800,000 AED, in this situation, the bank never returns profit margin, and he bears losses at 200,000 AED.

\section{Mudarabah Financing}

In any contract of Mudarabah, the Islamic bank will provide the entrepreneur of the capital he asks for, and he should contribute with his management and experience. Also, the loan will be borne by the bank while the profit will be shared on agreed base, Accounting and Auditing Organization for Islamic Finance Institution (AAOIFI). Shariah standards for Mudaraba have certain rules, these rules should be adhered from both parties 
for any finance contract and any contract has to get passed from Sharia compliant, any customer wants to involve in Mudarabah finance will become Mudarib, the bank or the institution will provide him with Islamic finance service (IFI) and he/she will become (Rab al mal) all of this and will be on an agreement between bank and customer and this will establish an executed transaction via Mudarabah contract (Ausaf Ahmad, 1993).

(1) Memorandum of understanding (MOU) will be followed by execution of all multiple Mudaraba contracts or Mudarib contract.

(2) The state of MOU:

1. Mode of intended financing i.e. unrestricted or restricted instrument of mudaraba finance.

2. Mudarib should bear a pre-agreed percentage to cover any losses that appear from negligence breach of misconduct of contact.

3. Profit allocation ratio.

\section{Types of Mudaraba Tools}

Mudaraba financing has two main types: restricted and unrestricted. In restricted contract, the capital of (Rab al mal) will have the authority to manage the fund but with certain restriction. For instant country exposures, however, in unrestricted the Mudaraba contract allows the capital to manage the funds without any restriction and Mudaraba capital must be intangible asset or cash.

In Mudaraba, there are links between Maqasid al-Shariah and Islamic economy (The Application of Maqasidal-Shariah in Islamic Finance, n.d.). The study reported that the bank will be a supplier and the borrower will take the money to start the project, whenever he gets the profit, it will be shared on an agreed base. In this situation, the bank will take his original money and the profit; furthermore, it is concluded that no gap is found in Mudaraba.

\section{The Practical Dimension of the Islamic Banking Format of the Mudaraba Contract}

A client who is unable to finance an asset requires financing for that asset and thus approaches the bank.

Since the Islamic bank cannot lend the client money in return for interest, the bank offers to buy the required asset from the seller in order to gain ownership, which is an Islamic pre-requisite for it is able to sell the asset to the client.

The cost of purchasing the asset from the bank is calculated (entailing the cost of the goods $+\%$ percentage marked up by the bank). Other legal and administration costs are then also added in order to calculate the final cost. The \% percentage marked up by the bank varies in relation to the period of repayment and is also determined by Islamic banks in non-Muslim and Muslim countries via the current interest rates of conventional banks.

Normally, any up-front payments towards financing the asset sought by the client are deducted, and a mark-up is placed only on the amount financed. For example, in car stuffs, the value of any car traded in as part of the sale is deducted from the purchase price of the car that is purchased.

If the customer accepts the final and calculated or pre-determined cost of purchasing the asset from the bank, the bank purchases the asset from the seller and sometimes profits through receiving a cash discount. If such discounts are received, the asset cannot be sold on the basis of a Murabaha if the discount is concealed. However, prior to purchasing the asset, the bank also has the client signed a legally binding contract that he will subsequent to the bank's purchase that asset himself from the bank for the specified amount. The bank will not buy the asset unless the (potential) buyer's promises to purchase are binding. The asset is either purchased directly by the bank or, as is customary, the client is asked to act as an agent on behalf of the bank. An agency 
agreement is concluded in which the client is also authorized to take delivery of the goods. However, the supplier of the goods shall invoice the bank and not the agent for the goods. This requirement has been waived by some banks in order to meet local tax requirements.

The bank bears any risks from the date of delivery by the supplier to the bank until the date and time of resale of the asset to the client.

Ownership is transferred to the client only after full payment of the purchase price. In the interim prior, the bank retains constructive possession.

Clients are obliged to insure the assets at their own cost, even though owner-ship may not have been legally transferred to them.

\section{Musharaka (or Sharika) Financing}

Musharaka is partnership between the client and the bank as each of them participates in the contract either on assets or working capital, furthermore the Musharaka contract has no fixed rules, each of the contracts is dealt with on its own worth, there is no restriction on the contract, so it means one contract might last for couple of weeks or even couple of years. Profit share in the contract is based on the agreement between the parties as they discussed and agreed on. But in some cases of loss, it will be shared by the capital provider. So, in few words, Musharaka contact is simply, a contract between two partners, each of them participates in projects in forms of cash or expertise and they share the profit and loss depending on the contract that has been agreed between both of the parties (Totaro, 2009).

In Musarkaha finance, there is a gap between the bank and Maqasid al-Shariah as typically the bank has the opportunity to cancel the agreement any time, as soon as the bank finds any fault from the customer or if there is any risk that might affect the bank.

\section{Salam (Baie al Salam)}

Salam is a sale where the seller undertakes to supply a specific product to the buyer at a future date, so they can agree on a specific price and a specific delivery time as agreed in the contract. This Islamic type of finance was created to meet the needs of small farmers who required money to grow their crops as they were allowed to sell some of their products in advance and after collecting the new crops they can return the money or profit to the bank. Salam can be used for the type of products where the quality and quantity can be measured in advance. For instance, it cannot be used for vegetables or fruits as there is a probability that the tree might be destroyed before the yield (Figures 6 and 7).

In salam (baie al salam), there is a gap between the bank and Maqasid al-Shariah as typically some banks might misuse the gap in baie al salam which contains a high risk for some banks, for example, a customer borrowing the money has the opportunity not to give the money back for any reason so the bank will not take the risk and they will charge high profit to be in the safe side, as they might create their own fatwa to support themselves (Figure 8) (The Holy Qur'an, Al-Baqarah, 2:278).

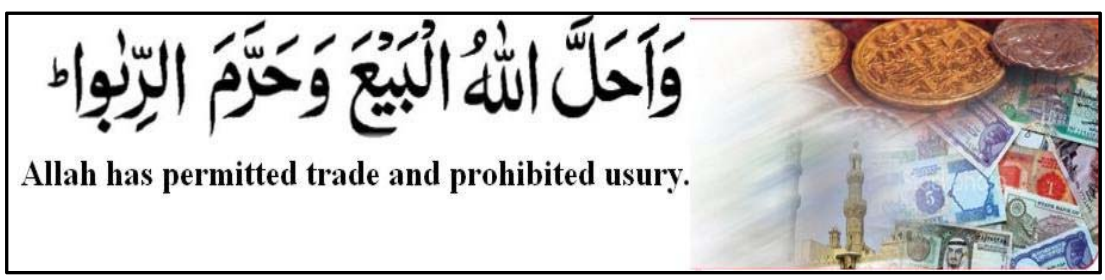

Figure 6. Quran verse of prohabiting interst (The Holy Qur'aan, Al-Baqarah, 2:275). 


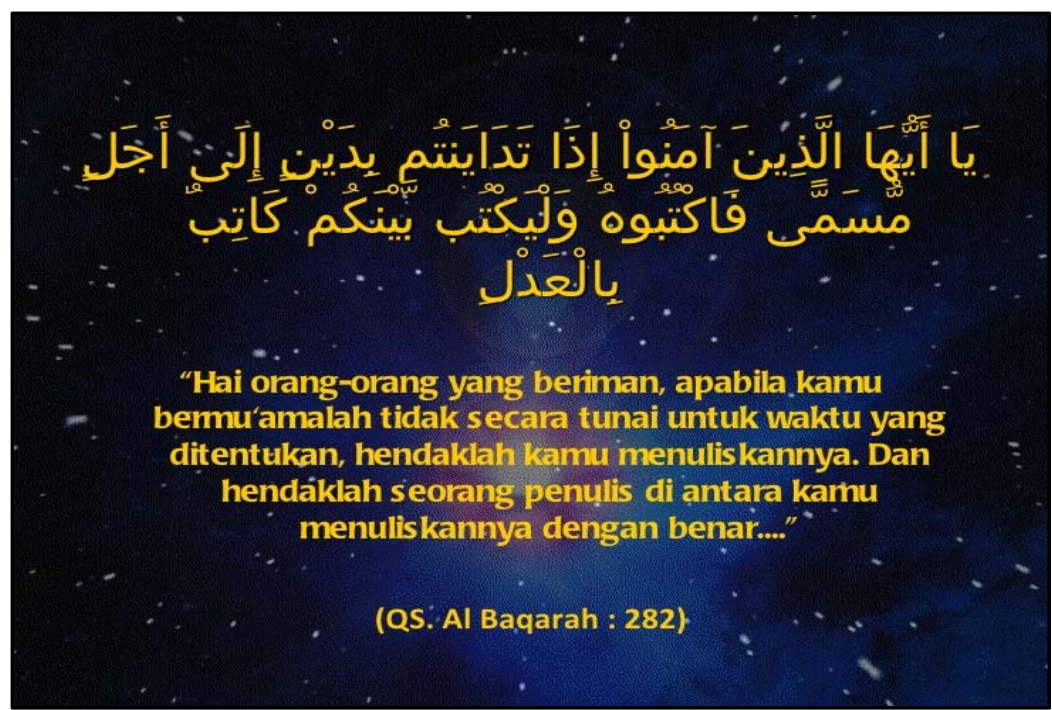

Figure 7. Quran verse of contradiction of (baie al salam) (The Holy Qur'an, Al-Baqarah, 2:278).

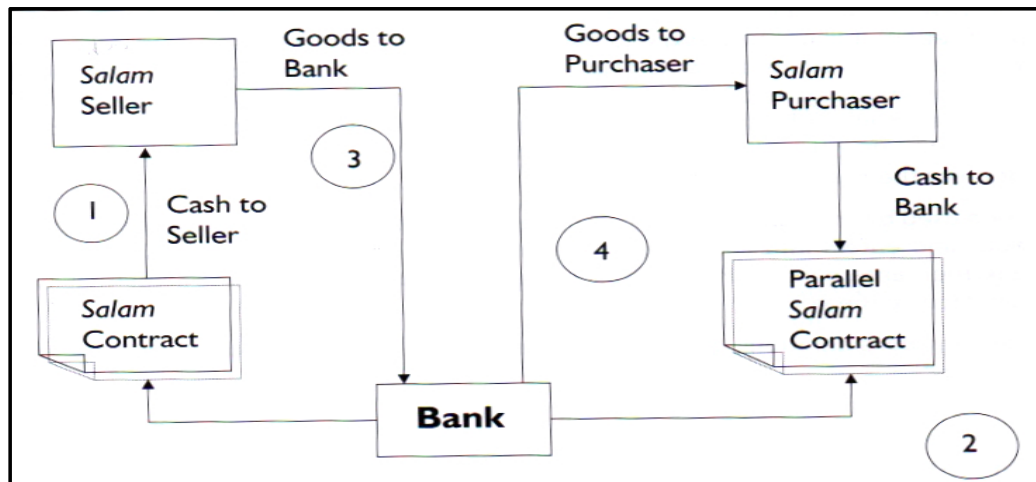

Figure 6.3: Salam and Parallel Salam Contracts

I. The bank enters a Salam contract with the seller and pays cash for future delivery of goods.

2. The bank enters a parallel Salam contract with the purchaser who will purchase the goods from the bank when they are delivered.

3. The goods are delivered to the bank.

4. The goods are delivered to the purchaser who pays the agreed price to the bank.

\section{Parallel Salam}

The IFI can sell the goods to a party other than the Salam customer (or a company which is owned less than I/3 by the Salam customer).

The Parallel Salam contract must be independent of Salam contract. The obligation of the IFI to deliver the goods under the Parallel Salam is not conditional on the performance obligations under the original Salam contract.

Figure 8. Mechanizm of (baie al salam) in Islamic banks.

\section{Ijarah}

Ijarah term means to give something on rent, literally, it can be utilized for specific transaction when the service is provided for someone in exchange for something. For example, hiring (renting) a lawyer or an engineer to provide a service for exchange of money. However, in renting a specific property, there is a third party, the third party will benefit from the profit but the ownership remains the same. 
There is a contract for leases for specific period that has been agreed among all the parties (Ausaf Ahmad, 1993).

\section{Type of Ijarah Contacts}

(1) The rental paid for specific duration of the leases.

(2) The lessor unilaterally agreed to sale the rental at the end of the period.

In Ijarah, the study did not see any gap because it's simply a deal between the tenants and rented, they rent a product or a service to a client and in this situation there is no risk for the banks and the parties involved (Figures 9, 10, and 11).

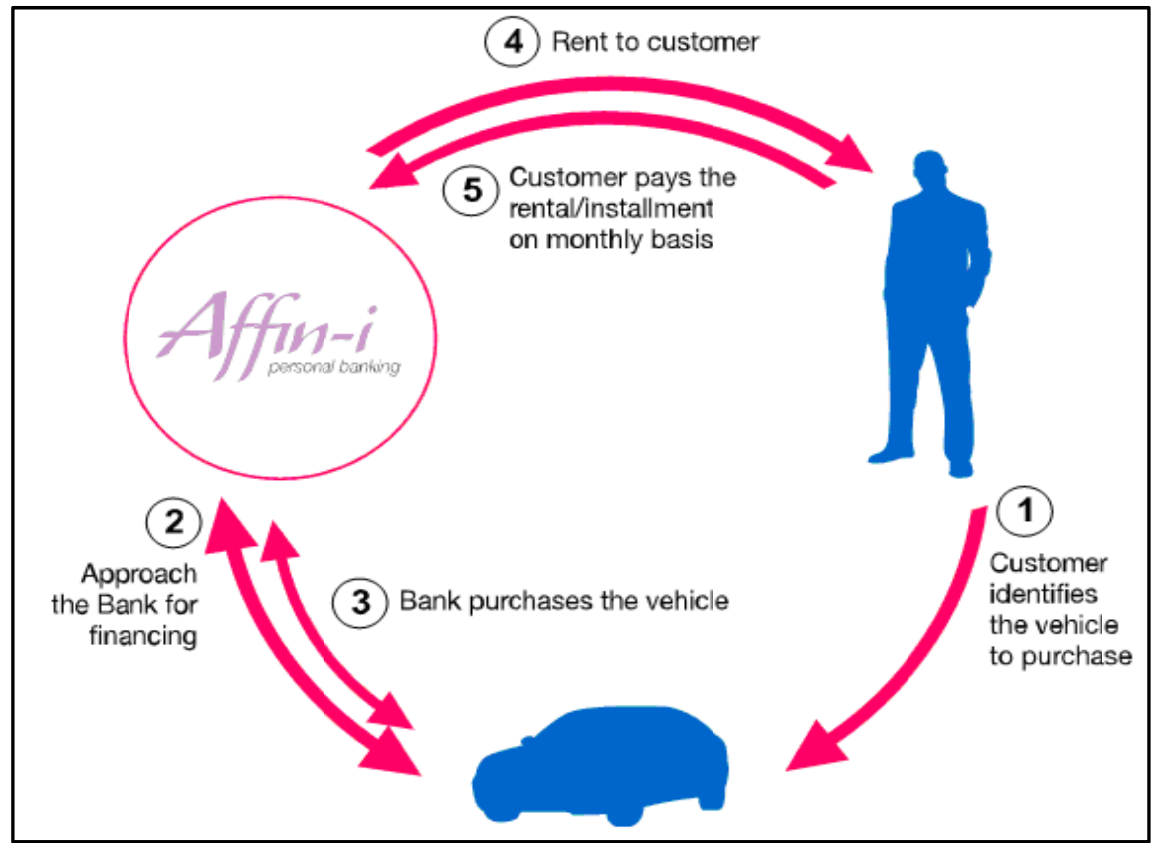

Figure 9. The mechanizm of Ijarah.

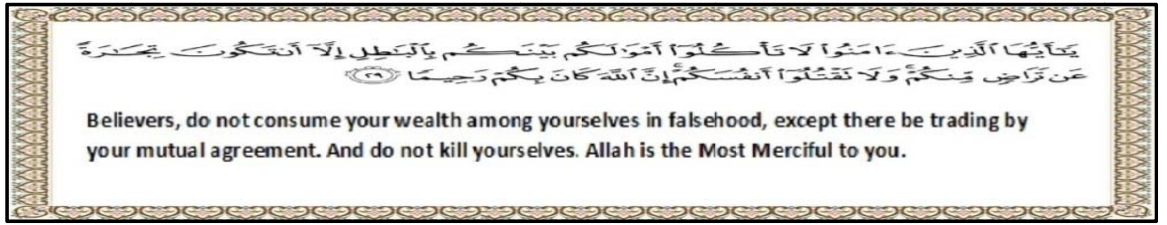

Figure 10. Quran verse to explain Ijarah (The Holy Qur'an, Al-Imran, 3:130).

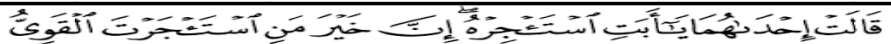

$$
\begin{aligned}
& \text { (1) }
\end{aligned}
$$

One of the two women said: "Father, hire him. The best who you can hire, is the strong, the honest.

Figure 11. Quran verse to explain Ijarah.

\section{Investment Instruments}

These are vehicles for capital instruments as an association.

- Mudarabah (المضاربة): A fund administration instrument could be short, medium, or long term, whereby a financial specialist deposits money to operators to attempt a task.

- Musharakah (المشاركة): A value organization instrument which could be either medium or long term 
association, where two or more persons join either their capital or their work to share the profit and losses.

\section{The Sukuk Market}

- Sukuk are investment certificates (Islamic Bonds).

- Sometime, they represent "ownership" in the assets underlying the issue.

- Those with variable profits are based on Mudarabah or Musharakah.

- More pervasive are those with pre-picked and adjusted wage. The clearest of these is the one considering ijarah, i.e., rent or use. A building (or an oil tanker) is procured and leased; the cash paid for buying the asset and then leased to the borrower should be pre-agreed by the two parties. Proprietors of these affirmations would meet all pre-requisites for getting a touch of the rent.

- These certificates can be traded in the market. These assets are sold by the originator to a Special Purpose Entity (SPE) and then are leased back at a specified rent. The SPE securitizes the assets by issuing Sukuk certificates that can then be purchased by investors.

- There are Sukuk based on Salam or istisna' contracts (Agricultural produce or manufactured goods to be available in the future may form the basis of salam/istisna' bonds).

- Also there are hybrid issues whose underlying assets are mixtures of these.

- Murabahah receivables being debt obligations are not considered fit for Sukuk issue, but they have been accepted in such a mixture as long as they are in a minority.

\section{Islamic Financial Institutions}

Islamic banks. These come as a half of customary business banks and venture banks. They might fit in with the general population or private part.

Islamic windows (in conventional banks). These are uncommonly setups that offer Shariah-agreeable items.

Islamic investment banks \& funds. These are "planning to profit by substantial venture syndications, market-production and under composing opportunities".

Islamic mortgage companies. These companies' objectives are fundamentally to lodge the market for Muslim groups in western nations. They act through usage of:

- Ijarah إجارة.

- Diminishing Musharaka (Equity partnershipة مشاركة متناقصة

- Murabahah (Sales transaction معاملة بيع).

- Along the lines of corporative societies.

\section{Islamic Insurance Companies (Takaful التكاففل)}

The Takaful means a given solidarity, a common or joint surety, whereby the members attempt to share their misfortunes by contributing intermittent premiums as venture. They need to recover the lingering estimation of benefits in the wake of satisfying cases and premiums, which is a basic distinction between contemporary protection and Takaful.

\section{Mudharaba Companies}

Similar to that of closed-end fund managed by specialized professional management companies, unlike the Islamic bank, they are not allowed to accept deposits, funded by equity capital.

These may be multipurpose (more than one venture reason), or specific reason organizations. 


\section{Outline of the Basics of Islamic Finance}

- Usury-free practices.

- Risk-sharing.

- Divinity of honouring contracts.

- Moral/Ethical dimension.

- Socio-economic background (empathy, equity, and fairness).

\section{Analysis of Islamic Financing Methods by Islamic Banks}

It became clear that the theoretical side is posed by intellectual sources, the initial system is the primary method of posts which must rely upon the Islamic banks and that's because of the positivity of this system on the side of economic conditions. Is the practical application of the way of Islamic banks in line with this proposal?

To find out the reality of Islamic finance in the practical application, the study will examine the relative distribution of the Islamic financing methods in some Islamic banks, and it has chosen a group of Asian Islamic banks as a model for the study through funds provided by these banks in the period from 2012 to 2014 analysis.

Table 1

Malaysian Bank

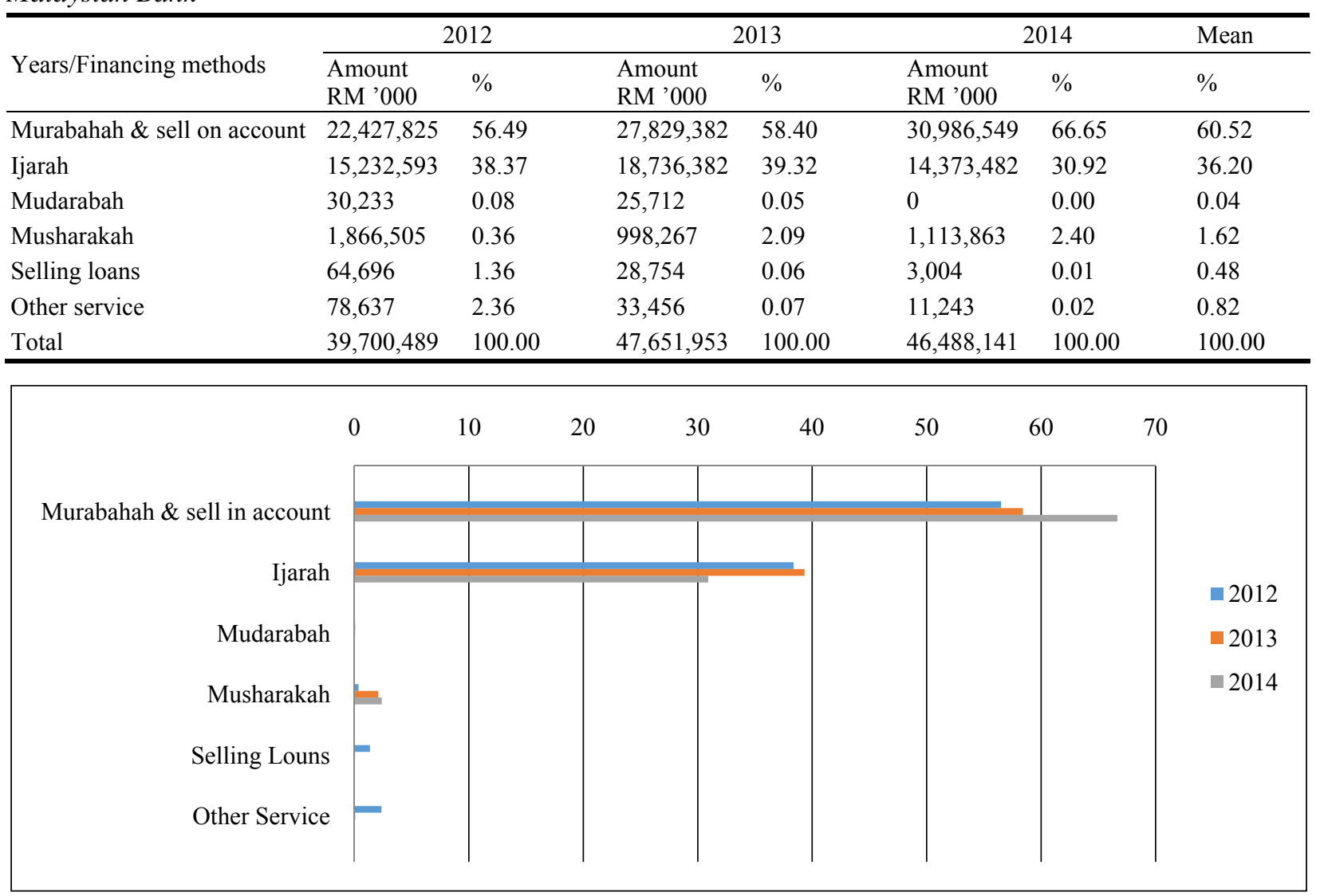

Figure 12. Allocation of Islamic financing tools at Malaysian Bank.

From Table 1 and Figure 12, the displayed data become clear as follows: 
(1) Murabaha and forward sales ranked first in total funds with an average of $60.52 \%$.

(2) Then comes the leasing, which ends with ownership weighing as much as an average of $36.20 \%$.

(3) Mudarabah and Musharakah occupied a very marginal importance of reaching an average of $1.62 \%$ for the post of diminishing while for the non-existent of Mudarabah, it's only $0.04 \%$.

(4) Bank did not use the process of Mudarabah in their financing in 2014.

(5) The absence of some other financing methods such as al Salam and Istisna during all the years of studies.

Table 2

Qatar Islamic Bank

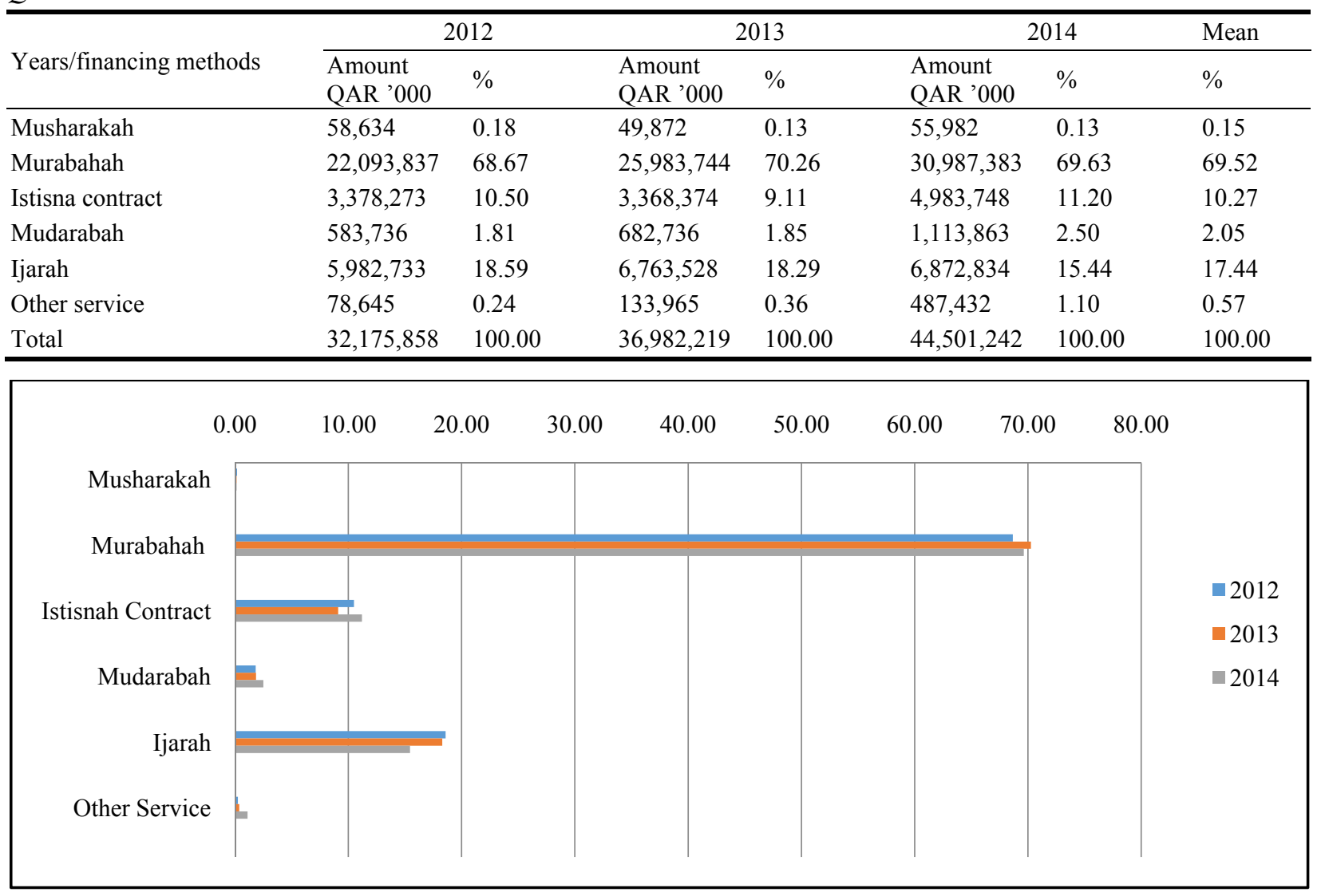

Figure 13. Allocation of Islamic financing tools at Qatar Islamic Bank.

From Table 2 and Figure 13, the explanations are as follows:

(1) Murabaha comes in the first priority in financing tools by the bank with an average of $69.52 \%$.

(2) Leasing ended by ownership comes in second, with an average of $17.44 \%$.

(3) Mudarabah and Musharakah occupied a very marginal importance of reaching an average of $2.05 \%$ for speculation while virtually non-existent for the Musharakah, as it stood at $0.15 \%$ only.

(4) The absence of some other financing methods such as al slam and Alasisnaa during all years of studies.

(5) Noting that: Murabaha and Alsaomat continue to increase over three years although the rates of increment, there is an indication of growing interest of the bank to these tactics.

(6) Mudarabah, leasing, and Istisna continuously decline in all years of study. 
Table 3

Jordan Islamic Bank

\begin{tabular}{llllllll}
\hline \multirow{2}{*}{ Years/Islamic financial service } & \multicolumn{3}{c}{2012} & \multicolumn{2}{c}{2013} & & \multicolumn{2}{c}{ Mean } \\
\cline { 2 - 8 } & Amount & $\%$ & $\begin{array}{l}\text { Amount } \\
\text { JD ’000 }\end{array}$ & $\%$ & Amount & $\%$ & $\%$ \\
\hline Murabahah & 876,376 & 67.84 & 856,767 & 66.00 & 909,873 & 69.06 & 67.63 \\
Sell in account & 2,182 & 0.17 & 2,767 & 0.21 & 3,028 & 0.23 & 0.20 \\
Rent end up with owns & 398,298 & 30.83 & 422,873 & 32.58 & 387,873 & 29.44 & 30.95 \\
Musharakah & 14,987 & 1.16 & 15,676 & 1.21 & 16,787 & 1.27 & 1.21 \\
Total & $1,291,845$ & 100.00 & $1,298,085$ & 100.00 & $1,317,563$ & 100.00 & 100.00 \\
\hline
\end{tabular}

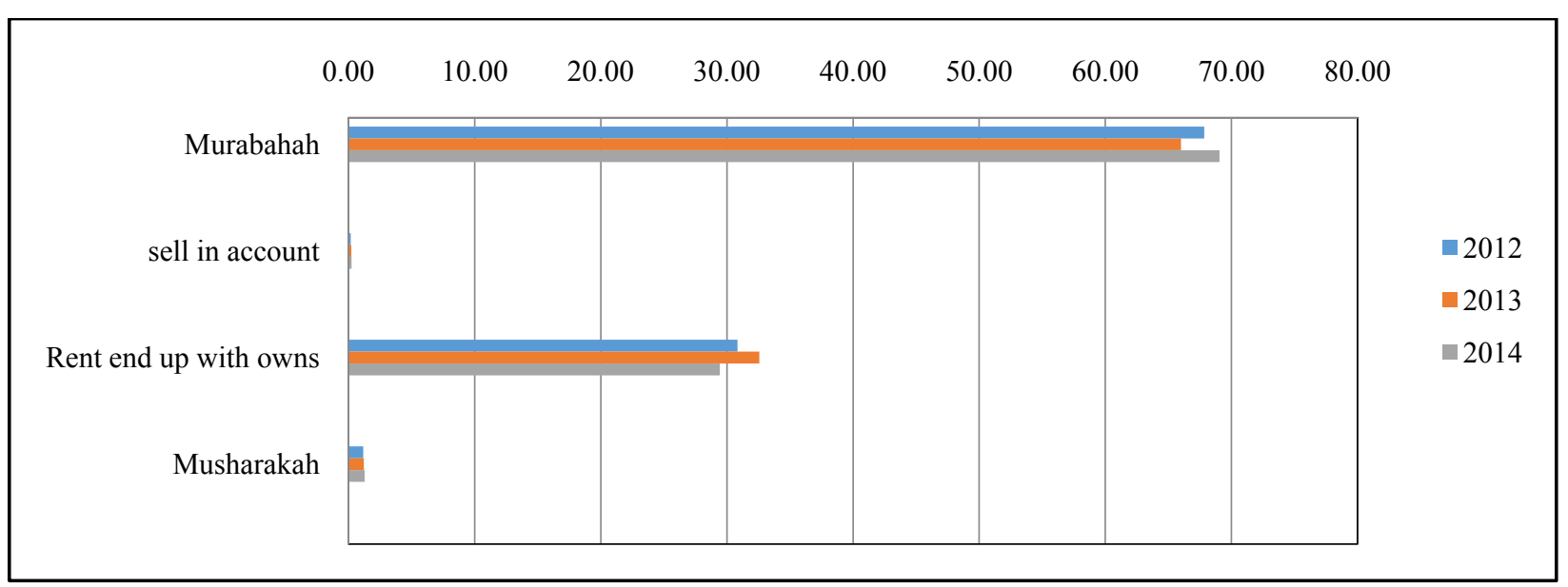

Figure 14. Allocation of Islamic financing tools at Jordan Islamic Bank.

From Table 3 and Figure 14, the data shown above give a clear picture which is as follows:

(1) Murabaha holds the lion's share of the other modes of financing where Murabaha ranked first with an average estimated $67.63 \%$.

(2) What comes in second place is the rent ended by ownership with averaging $30.95 \%$.

(3) Musharakah weight appeared very weak, where it reaches an average of only $1.21 \%$.

(4) The bank did not depend on Mudarabah during the three-year study.

(5) Not only Mudarabah formula is absent from the methods of financing in the bank, but also absence of both the peace and also Istisna.

(6) Noting: Murabaha recorded a steady decline in three years, but in very small amount which did not affect the acquisition of this formula on the bulk of the funding plans which did not go down to $80 \%$ during these years.

Table 4

Al Rajhi Bank

\begin{tabular}{|c|c|c|c|c|c|c|c|}
\hline \multirow[b]{2}{*}{ Years/Islamic financial service } & \multicolumn{2}{|c|}{2012} & \multicolumn{2}{|c|}{2013} & \multicolumn{2}{|c|}{2014} & \multirow{2}{*}{$\begin{array}{l}\text { Mean } \\
\%\end{array}$} \\
\hline & $\begin{array}{l}\text { Amount } \\
\text { SAR '000 }\end{array}$ & $\%$ & $\begin{array}{l}\text { Amount } \\
\text { SAR '000 }\end{array}$ & $\%$ & $\begin{array}{l}\text { Amount } \\
\text { SAR '000 }\end{array}$ & $\%$ & \\
\hline Trading & $44,898,374$ & 32.75 & $41,727,342$ & 30.15 & $49,873,874$ & 32.37 & 31.76 \\
\hline Murabahah \& installment & $90,938,728$ & 66.33 & $95,637,872$ & 69.11 & $102,983,748$ & 66.84 & 67.42 \\
\hline Istisna contract & 598,940 & 0.44 & 293,892 & 0.21 & 398,273 & 0.26 & 0.30 \\
\hline Other service & 673,622 & 0.49 & 728,273 & 0.53 & 827,363 & 0.54 & 0.52 \\
\hline Total & $137,109,664$ & 100.00 & $138,387,379$ & 100.00 & $154,083,258$ & 100.00 & 100.00 \\
\hline
\end{tabular}




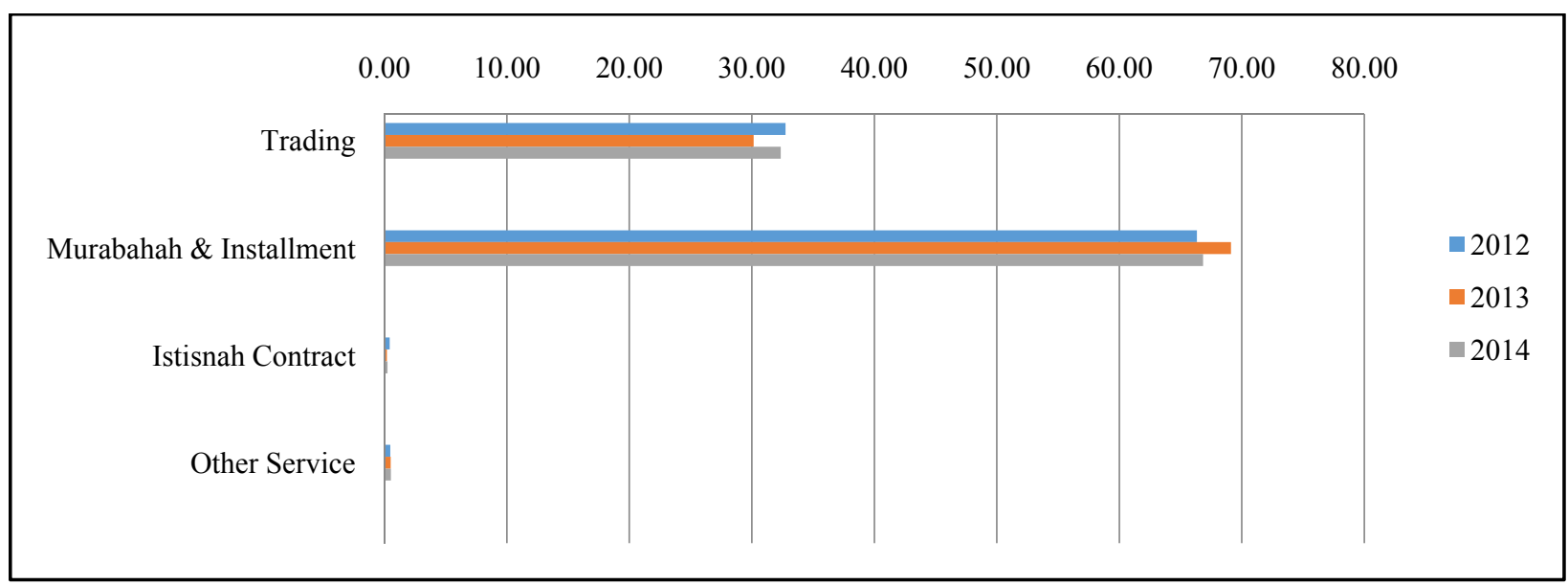

Figure 15. Allocation of Islamic financing tools at Al Rajhi Bank.

From Table 4 and Figure 15, the data become clear as follows:

(1) Bank is depending primarily on sales formats.

(2) Murabaha and instalment sales occupied the first place among the funding formulas and reaching an average of $67.42 \%$.

(3) Murabaha and instalment sales recorded a steady position during the three years and reached their highest level in 2013, where as much weight to $69.11 \%$.

(4) Al Rajhi Bank has not used any methods of Musharakah during all the years of the study.

(5) That not be considered to participate is the only way that the bank has not been adopting their finance approach but the study finds other methods which have been neglected by the bank leasing, selling salam.

\section{Study Findings and Evaluation}

After studying and understanding the theory and practice of Islamic financing in Islamic banking system, the study raised the following three questions below:

(1) Do banks misuse the rules and norms of Maqasid Al Shari'ah, and if yes in what ways?

Presently, few Islamic banks are dedicated in taking after Shari'ah Rules and agreeing to Maqasid al Shari'ah.

In any case, the greater part of Islamic banks is abusing the standards of Maqasid al Shari'ah, by practically adhering to shallow or poor translation of the all-inclusive statements of Islamic Law, while "shying-endlessly" from the genuine objectives of Islamic Law and the Socio-Economic Values of Islam that are exemplified by Social Justice, Fairness, Empathy, Equity, and so forth.

These banks are rolling out improvements in the general comprehension of Islamic rules under the "standard" of modernisation that keeps Shari'ah "adaptable" and utilizable in each time and put. Their "invented" rationale here is that: Islamic banking could increment hazard because of such elements as the many-sided quality of Islamic credit contracts, restricted default punishments and good peril motivating forces brought about by PSLB (profit sharing and lose bearing) contracts.

The Buy-Back Arrangements, for instance, are broadly utilized as a part of all divisions of the economy including managing an account fund. Being that as it may, there are not kidding reservations among scholars with respect to the legitimacy of purchase back courses of action. "Such plans may be a minor subterfuge to go 
around the denial of Reba". Purchasing and offering in the meantime are just another strategy for loaning on hobby. Moreover, offering something which one does not have is abusing another Islamic standard.

Islamic banks are gradually abandoning the ethical norms of Islamic finance. The basic principles of Islamic ethical norms elucidate that:

- Islamic finance supports adjusted exchanges: Lenders must impart benefits or misfortunes to borrowers.

- Islamic finance rejects "creating" cash from cash, on the grounds that the part of cash in Islam is "worth characterizing" and a medium for trade.

- Islamic finance disallows the expansion of credits for securing or putting resources into illegal merchandise, (for example, pork and alcoholic) or serves (for example, betting, usury, and extortion).

- Islamic finance rejects contracting under high hypothesis (Gharar), as this prompts misusing or imperilling "the powerless".

- Islamic finance rejects the deal and the buying obligations of any business sector with pre-determined profit and loss sharing, it will be regarded Riba, which is restricted in Islam for the reasons of exploitation and human felicity.

(2) Who is responsible for the misuse of the rules and norms of Maqasid Al Shari'ah?

Directly responsible for the abuse of the guidelines and standards of Maqasid Al Shari'ah is stated below:

The Senior Management of Islamic Banks, due to either: (1) Academic impatience for implementing a "brisk fix", an "Answer", for the "issues" thwarting the development of the moderately are much "more youthful" Islamic Banking in the opposition with the more experienced traditional banking that controls the worldwide money related markets. This accompanies a "satisfactory" penance of "a few snags" (Maqasid Al Shari'ah); and/or (2) professional ambition for accomplishment of "eminence" and notoriety for accomplishing high benefits, by any methods; and/or (3) personal ambitions for fulfilment of "record" results that "entice" contributors and customer base, this manner brings about the extension of the base of customers of the bank, and along these lines securing them advancements and rewards.

The members of the Sharia Supervisory Boards, whose capacity is to go about as review and oversight for guaranteeing bank consistence with Shari'ah Law and its dedication is to apply Maqasid Al Shari'ah. These tend to side bank administration and acknowledge and "advertise" the "obscured" and contorted sentiment and vision of the administration about the Islamic Law, and "be permissive" in the support of these perspectives which progressively forsake the quintessence of Maqasid Al Shari'ah. Individuals from these boards take after their own advantage, really being "remunerated" by the bank to assume a submission part for the reluctant open and potential clients, and for embracing routes for "danger evasion".

Indirectly responsible for the abuse of the principles and standards of Maqasid Al Shari'ah is the bank customers, who intentionally incline toward "Islamic-ally un-legitimate" benefits and profits to their religious responsibility and immaculateness of inner voice.

\section{Why Islamic Banks Focusing on Murabaha in Their Financial Resources?}

Clearly illustrated by the previous study that Islamic banks go to sales formats, led by Murabaha in the recruitment of financial resources and at the expense of Musharakah formats and this tendency is because of several important reasons as bellow:

(1) Lack of risk in Murabaha transaction because of taking guarantees that client well paid, in contrast with the other finance methods specially if there weren't any previous deals. 
(2) Easy processing in Murabaha contract, where the employees of the bank do not spend any efforts in studying or following or having responsibilities with the owner like Musharakah.

(3) Financing or resources available to the bank in the Islamic mostly come from short- or medium-term and that are capable with methods of Murabaha, also sale includes fixed return that agreed and signed in Murabaha contract between the bank and the customer.

(4) Employee of commercial bank faces same procedure like what they work on in credit department.

(5) Customers who have dealt for so with conventional banks on the funding formula have benefit when turn them to deal with Islamic banks that this formula is appropriate especially with regard to non-interference by the bank in their business after receiving financing and in order to preserve their secrets to their desires and this is what is not available in Musharakah.

(6) Murabaha does not require the implementation of the bank, but the existence of a specialized expertise is required and in Murabaha process, the banks do not need to keep or store the purchases item, so the cost is less.

(7) Lack of employee experience and expertise in the Islamic banking methods and investment and other formats make them vary of risk taking, especially if the bank has some successful experiences of other banks.

\section{Recommendations}

In light of the results obtained previously, it is clear that this group of banks is almost similar in terms of the degree of dependence on financing methods to apply their resources where noted that the adoption of the majority of these banks in its funding formulas on sales, particularly to Murabaha is the main reason for the gap between theory and practice which result to have negative impact on economic conditions, so the experts and specialist should work on to achieve the following objectives:

(1) Activate the Islamic financial methods based on participation in the profit and loss of funding tools by the following:

- Careful selection of clients with new financial records, and who deal in accordance with the financial rules and norms of customary accounting and adhere issued by standards, so they have to have special department to deal with this issue.

- Restrict Mudarabah with conditions and restrictions that fit the ownership in all aspects of investment activity because the contract is the foundation upon disclaimer and the speculative or worker should be adhered to it and not violate it.

- Watching the stages or process before and after the work is done well leads to minimizing of losses or not to complete and achieve the desired profit.

(2) Do not rely much on Murabaha, to avoid the following negative effects:

- Reduces the ability of Islamic banks to finance large economic projects that require long-term funding that Murabaha is considered as a short-term approach in general.

- Murabaha sale contributes in the production of behavioural models that are unacceptable in Islam such as bias to quick profit; avoid the risk, the desire to increase profit margins and lack of attention to the other party in community.

- Attention to goods imported and ignoring of domestic goods affect the productivity of these countries. 


\section{Conclusion}

This paper studied the framework and components of Islamic economics, finance and banking, and the financing techniques utilised by Islamic financial institutions.

Twenty five years ago, the "young" Islamic finance had been at cross-roads. Then, in a haste being fuelled by the competition for profit and extensive revenues, it gradually started to move into ethically compromised practices. Thus, the operations of Islamic institutions and their modes of financing have expanded considerably, while individuals have been deprived from "tasting" the fruits of this enormous growth.

Currently, however, its distinctive feature of Islamic finance is the growing controversy between its original theory and current practice.

During these last 25 years, Islamic finance has grown and developed in such a way that it converged towards conventional banking methods, thus becoming, itself, a presenter and producer of hybrid financial products of the "interest-bearing" international financial system.

So, the "Grand" operations of the massive international financial markets - those which prioritise economic incentives rather than ethical, religious, and behavioural norms - have "tempted" Islamic finance institutions to become part of the "usurious" international financial system.

Also, it addressed the diagnosis and analysis of the reality of the Islamic bank financing in the practical application and this is in order to identify the extent of deviation of the Islamic bank from the theoretical frame and gets to know the extent of the need for these banks to reconsider their own way, so the study result to some of the findings and recommendations does not mean to ignore Murabaha but do not rely much on it while they apply it with right contract in terms of legitimacy and without fraud or intentional misuse.

The banks have rights to sell what God has permitted and humans do not deprive it, but if Islamic banks are able to distribute their investments by species, possibly such as Mudarabah, Musharakah, and al-slam, leasing with giving preference relative to formats of Musharakah, it will be a best practise between the banks and their clients.

Therefore, it has been the divergence among the assumptions, normative principles and aspirations of Islamic economics as a system and Islamic finance is an instrument of that system.

According to the study, several financing techniques such as Murabaha, Buy-Back transactions, deferred sale operations, etc. need to be carefully and thoroughly reviewed from the point of view of the Shari'ah Law and with a backdrop of Maqasid Al Shari'ah.

The study recommends the following steps to stem the gap in Islamic finance:

(1) Establishing an Islamic central bank to monitor and control the Islamic financing methods and match them with Islamic law.

(2) Shifting toward equity financing methods is gradually with a $5 \%$ average annual increase.

\section{References}

Archer, S., \& Abdel Karim, R. A. (2007). Islamic finance: The regulatory challenge. John Wiley \& Sons (Asia) Pte Ltd.

Ausaf Ahmad. (1993). Contemporary practices of Islamic financing techniques. Study Paper No. 20, Published by Islamic Study and Training Institute, Islamic Development Bank.

Choudhry, N. N., \& Mirakhor, A. (1997). Indirect instruments of monetary control in an Islamic financial system. Islamic Economic Studies, 4(2).

Hassan, K., \& Lewis, M. K. (2007). Handbook of Islamic banking. Edward Elgar Publishing Limited.

Hussein, A. (2012). Islamic finance risk-sharing and international financial stability. Yale Journal of International Affairs. 
Kahf Monzer. (2003). Islamic economics, notes on definition and methodology. Review of Islamic Economics, 13, 23-47.

Kahf Monzer. (2005). The success factors of Islamic banks: Islamic Study and Training Institute. Islamic Development Bank, Jeddah, KSA.

Manawar Iqbal. (2007). A comparing study between Islamic and conventional banks in the nineties Islamic Study and Training Institute. Islamic Development Bank, Jeddah, KSA.

Nasser Al Ghareeb. (2010). Islamic banking assets and operating issues, Islamic Study and Training Institute. Islamic Development Bank, Jeddah, KSA

Shaker, F. (2010). Islamic banking versus commercial banking: prospects \& opportunities, a presentation. FIRST EAST INVEST, Cairo, Egypt. (Dr. Fouad Shaker is a Senior Advisor \& Partner: First East Invest; and was the Former Secretary General: Union of Arab Banks).

The Application of Maqasidal-Shariah in Islamic $\quad$ Finance. (n.d.). http://www.maybank2u.com.my/iwov-resources/islamic-my/document/my/en/islamic/scoe/knowledge-centre/articles/Applic ation_of_Maqasid_al-Shariah.pdf

The Holy Qur'aan, Al-Baqarah, 2:275.

The Holy Qur'an, Al-Baqarah, 2:278.

The Holy Qur'an, Al-Imran, 3:130. (O you who believe! do not devour usury, making it double and redouble, and be careful of (your duty to) Allah, that you may be successful.)

Totaro, L. (2009). Vatican says Islamic finance may help western Banks in Crisis. 